\title{
Long-term open-water season stream temperature variations and changes over Lena River Basin in Siberia
}

\author{
Baozhong Liu ${ }^{\mathrm{a}}$, Daqing Yang ${ }^{\mathrm{a}, *}$, Baisheng Ye ${ }^{\mathrm{b}}$, Svetlana Berezovskaya ${ }^{\mathrm{a}}$ \\ ${ }^{a}$ Water and Environmental Research Center, Institute of Northern Engineering, University of Alaska Fairbanks, Fairbanks, \\ AK 99775-5860, USA \\ ${ }^{\mathrm{b}}$ Cold \& Arid Regions Environmental and Engineering Research Institute, Chinese Academy of Sciences, Lanzhou 730000, PR China
}

Received 21 October 2003; accepted 9 December 2004

\begin{abstract}
This study systematically analyzes long-term (1950-1992) stream temperature records for the major sub-basins within the Lena River watershed in order to describe water temperature regimes over the various parts of the Lena watershed and document significant stream temperature changes induced by reservoir regulation, and by natural variations/changes. The results show that the open water season can be divided into three consecutive stages - "increasing temperature stage" in the early open water season, "stable temperature stage" in the mid-warm season, and "decreasing temperature stage" in the late open water season. Temperature conditions are similar over the Aldan and Upper Lena regions. However, stream temperatures at the Lena basin outlet are up to $8{ }^{\circ} \mathrm{C}$ lower than those over the southern sub-basins. This suggests that the latitudinal difference in climatic variables, such as air temperature, might be the major control on stream temperature regime. Results also demonstrate that the reservoir regulation has a strong influence on the regional water temperature regime and change in the regulated subbasin. Reservoir regulation has increased (decreased) the downstream water temperatures in the Vilui valley during the early (mid) open water season. Trend analyses show consistent warming trends across the entire Lena River basin in the early open water season. This may indicate a response to earlier snowmelt over the Lena River watershed. Trend results also demonstrate that the Aldan tributary, without much human impact, experiences warming (cooling) trends in the first (second) half of the open water season, leading to a stream temperature regime shift toward early open water season. The upper Lena River has warming (cooling) trends in the early (mid-late) open water season. Over the regulated Vilui tributary, however, stream temperatures have significantly increased in the early and late parts of the warm season due to combined effects of natural changes and reservoir regulation. Over the Lena basin as a whole, strong positive correlations have been found between the basin mean monthly air and water temperatures during the warm season. Increasing water temperatures were observed during the early and mid-June. Because of stream temperature increase in this peak flow period, the Lena River heat flux has gone up by $23 \%$ in June. This may have considerable impact on the thermal conditions of the Laptev Sea in the early summer season. (C) 2005 Elsevier B.V. All rights reserved.
\end{abstract}

Keywords: Lena River; stream temperature; regime and change; reservoir impacts; Arctic Ocean

\footnotetext{
* Corresponding author. Tel.: +1 907474 2468; fax: +1 9074747979.

E-mail address: ffdy@uaf.edu (D. Yang).
} 


\section{Introduction}

River runoff is the primary freshwater source to the Arctic Ocean. Freshwater discharge from north-flowing rivers plays an important role in regulating the thermohaline circulation of the world's oceans (Aagaard and Carmack, 1989). Recent studies find that most northern rivers, including the largest arctic rivers in Siberia, show an increasing runoff trend, especially in winter and spring seasons, over the last several decades (Grabs et al., 2000; Lammers et al., 2001; Nijssen et al., 2001a,b; Zhang et al., 2001; Peterson et al., 2002; Serreze et al., 2002; Yang et al., 2002; Ye et al., 2003). The causes for these changes are not all clear. It has been suggested that spring discharge increase in Siberian regions is primarily due to an earlier snowmelt associated with climate warming during snowmelt period (Nijssen et al., 2001a,b; Serreze et al., 2002; Yang et al., 2002, 2003). Changes in winter streamflow are perhaps associated with reductions in permafrost extent, increases in active layer thickness under a warming climatic condition (Serreze et al., 2002; Yang et al., 2002), and also due to reservoir regulation (Ye et al., 2003; Yang et al., 2004).

Stream temperature is a direct indicator of river thermal condition. River thermal conditions affect biological processes. Studies have recognized river thermal regime as the primary physical factor influencing aquatic communities (Lake, 1967; Hynes, 1970; Lowney, 2000). The natural temperature regime of a river provides thermal cues that stimulate responses in many aquatic species, such as fish spawning, insect emergence and egg hatching (Lake, 1967; Ward and Stanford, 1979; Petts, 1986). For instance, fish are poikilothermal animals and stream temperature has a significant effect on the diseases they may host. In the high latitude regions, river thermal regime is one of the key factors that influence the freeze-up/break-up processes, thickness of river ice cover, and thermal erosions along the riverbanks. Marsh and Prowse (1987) studied the influence of stream heat on overlying ice cover of the Liard River, and discovered large spatial and temporal variations in water temperatures and heat fluxes. Mackay and Mackay (1975), based on long-term field observations of water temperatures at three locations in the Mackenzie River, defined the basis thermal regimes (such as seasonal changes), and quantified the river heat transport. Costart et al. (2003) reported that the major factors controlling the thermal erosions of the frozen riverbanks in the Lena basin are water temperature and discharge, and relatively water temperature is more important than streamflow amount.

Stream water temperatures follow two cycles: a seasonal cycle and a diurnal cycle. Stream and air temperature data show that water temperatures follow air temperature closely on a seasonal time scale (Sinokrat and Stefan, 1993). Because of climate warming, stream temperatures have increased over some regions. These elevated water temperatures have become an important concern in watersheds where aquatic species such as salmonids are present (Lowney, 2000). However, it is important to understand that, in addition to climatic factors, human activities, particularly the construction of large reservoirs, also impact river discharge and stream temperature over space and time. Recently, Lowney (2000) investigated the impact of reservoir operations on the diurnal variation in stream temperatures in the upper Sacramento River, and reported unusual spatial patterns in daily maximum and minimum magnitudes. Preece and Jones (2002) examined the modifications in stream temperature caused by the release of hypolimnetic water from thermally stratified reservoirs. They found that the effect was greatest immediately downstream of the dam where annual daily maximum temperature was approximately $5.0{ }^{\circ} \mathrm{C}$ lower and occurred three weeks later than the pre-dam condition. They concluded that this change was sufficient to disrupt thermal spawning cues for selected Australian native fish species.

Examinations of stream temperature changes and variations are important to quantify heat flux from the northern rivers into the ocean system (Bareiss et al., 1999). The main objectives of this paper are to investigate the long-term variations and changes in stream temperature over the Lena River basin, to assess the impacts of large reservoir on river thermal dynamics, and to calculate the Lena basin thermal flux into the Laptev Sea. The results of this study are critical in explaining hydrologic response to climatic changes and variations in the Siberian regions. They are also important to investigations of the thermal impacts of large north-flowing rivers on high-latitude ecology and ocean systems. 


\section{Basin description, data sets, and method of analyses}

The Lena River is one of the largest rivers flowing into the Arctic Ocean. It originates from the Baikal Mountains in the south central Siberian Plateau and flows northeast and north, entering into the Arctic Ocean via the Laptev Sea (Fig. 1). The drainage area of the Lena basin is about 2,430,000 $\mathrm{km}^{2}$, approximately $78-93 \%$ of which is underlain by permafrost (Zhang et al., 1999). The Lena River contributes 524 $\mathrm{km}^{3}$ of freshwater per year, or about $15 \%$ of the total freshwater flow into the Arctic Ocean (Shiklomanov et al., 2000; Prowse and Flegg, 2000). The drainage basin is covered mainly by forest $(84 \%)$, shrub $(9 \%)$, grassland (3\%), cropland (2\%), and wetland (1\%) (Revenga et al., 1998). Basin total population is about 2.3 million people, with one city (Yakutsk) having a population of more than 270,000. Compared with other large Siberian rivers, such as the $\mathrm{Ob}$ and Yenisei Rivers, the Lena basin has less human activity and much less economic development (Dynesius and Nilsson, 1994). The Lena basin has only one large reservoir (capacity greater than $25 \mathrm{~km}^{3}$ ), located in the west Lena basin built during the late 1960s.

Since the late 1930s hydrological observations in the Siberian regions, such as discharge, stream water temperature, river-ice thickness, dates of river freezeup and break-up, have been carried out systematically by the Russian Hydrometeorogical Services, and the

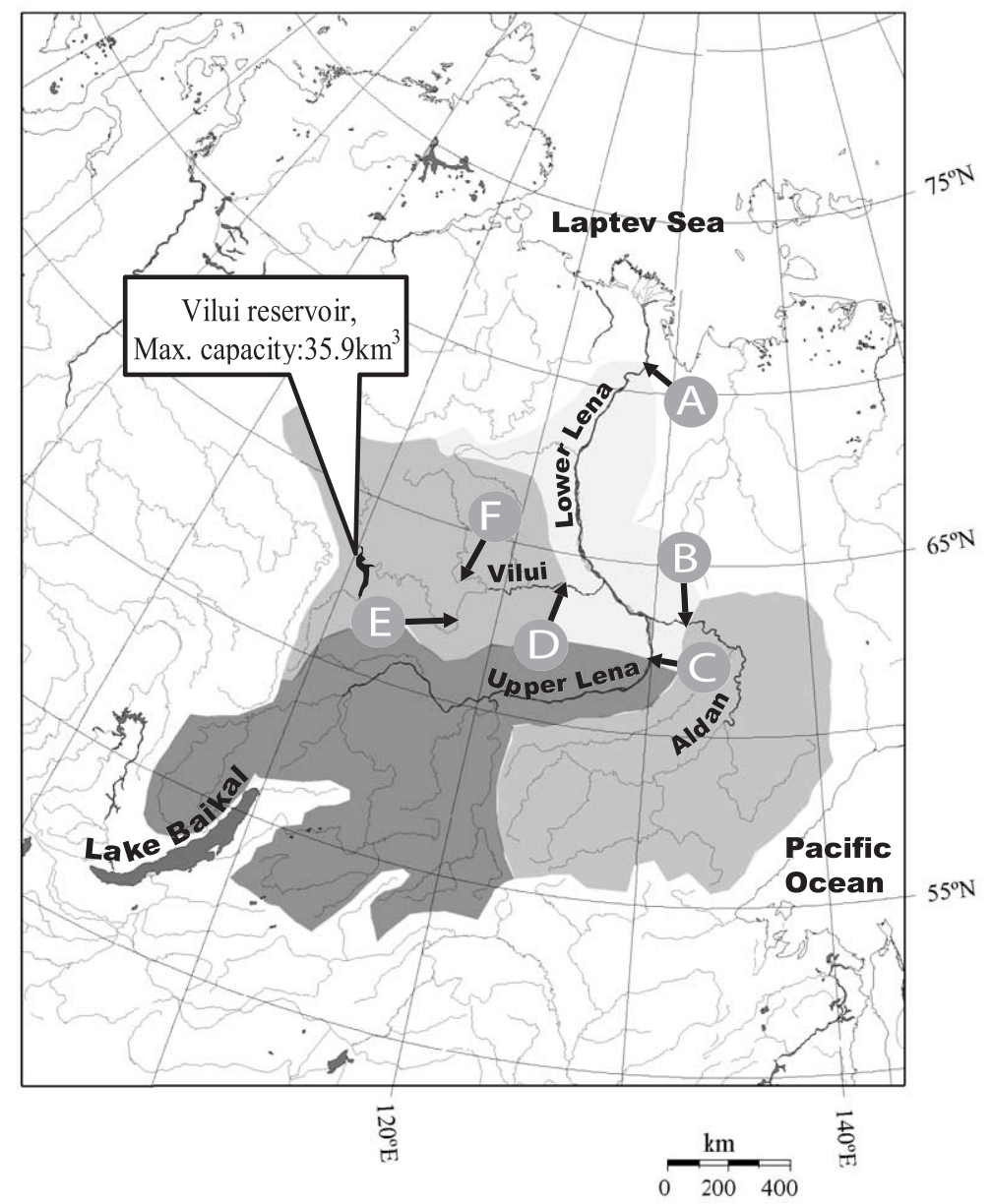

Fig. 1. The Lena River watershed and locations of hydrological stations used for this study. Also shown are sub-basin boundaries and reservoir location/information. 
observational records were quality controlled and archived by the same agency (Shiklomanov et al., 2000). According to the standard procedures for hydrometeorological observations in the former USSR (State Hydrologic Institute, 1975), stream temperatures were observed at the regional hydrologic stations three times a month (10th, 20th, and 30th day), and measurements were taken twice (at 8:00 A.M. and 8:00 P.M.) on each observation day. The observations were made near the river bank with flowing water deeper than $0.3-0.5 \mathrm{~m}$. For small rivers and rivers with offshore bars, measurements were taken at a location along the deepest channel. Occasionally, two measurements were taken, respectively, near bank and at the deepest channel to ensure the consistency of observations at different locations. Stream temperature observations usually start at the beginning of spring while the rivers are ice-covered and water temperatures are close to $0{ }^{\circ} \mathrm{C}$, and observations stop in fall season 3-5 days after the rivers freeze up. During observations, a thermometer (installed inside a cup) was placed at $0.3-0.5 \mathrm{~m}$ below the water surface for 5-8 $\mathrm{min}$, and the cup was retrieved carefully for a quick recording of temperatures. For certain temperature readings such as those below $2{ }^{\circ} \mathrm{C}$, a minor adjustment was applied according to the last thermometer calibration.

Quality of water temperature observations and their representativeness to mean river water temperatures are important for analyses of river thermal regime and change. Studies have shown that local conditions, such as topographic and vegetation effects, and groundwater recharge, influence temperature observations in small streams (Brown, 1969; Sridhar et al., 2004). For large rivers, lateral and vertical mixing of water is often very strong particularly during the high discharge periods, and groundwater advection is relatively insignificant (Brown, 1969; Sridhar et al., 2004). Although there are sometimes small vertical variations in water temperatures, water temperature observations taken near shore and near surface in large rivers are generally representative of the mean water temperature. A study in the Mackenzie basin concluded that water temperatures measured at a depth of $1 \mathrm{~m}$ below the water surface were reasonably representative of the flow passing the observation sites (Mackay and Mackay, 1975). Water temperature data have been considered as reliable indicators of river thermal conditions, and used for determinations of river heat content over the Mackenzie basin in Canada (Mackay and Mackay, 1975) and in large regions of the former USSR, including Siberia (State Hydrologic Institute, 1961; Elshin, 1981).

Stream temperature data collected at 105 stations in the Lena basin and its neighboring regions during 1950-1992 are available for our research. In this paper, we focus on analyses of stream temperature data at several major stations with $3-15 \%$ of missing data within the Lena basin. Relevant station information is summarized in Table 1. In order to study the influences of hydrology and climate on stream temperatures over the basin, we also use monthly discharge records, and the Lena basin-mean monthly temperature and precipitation data derived from the global datasets (New et al., 2000).

The approaches and methods of analyses are briefly summarized below. First, we compiled basin geophysical and hydrological information and identified dam-regulated (human impact) and unregulated (natural condition) sub-basins. Second, we calculated and compared long-term means of stream temperature

Table 1

List of hydrologic stations used in this study

\begin{tabular}{|c|c|c|c|c|c|c|c|}
\hline \multirow{2}{*}{$\begin{array}{l}\text { Station code } \\
\text { (see Fig. 1) }\end{array}$} & \multirow[t]{2}{*}{ Station name/location } & \multirow{2}{*}{$\begin{array}{l}\text { Lat. } \\
\left({ }^{\circ} \mathrm{N}\right)\end{array}$} & \multirow{2}{*}{$\begin{array}{l}\text { Long. } \\
\left({ }^{\circ} \mathrm{W}\right)\end{array}$} & \multicolumn{2}{|l|}{ Drainage area } & \multicolumn{2}{|c|}{ Annual runoff } \\
\hline & & & & $\times 1000 \mathrm{~km}^{2}$ & $\begin{array}{l}\% \text { of Lena } \\
\text { basin }\end{array}$ & $\mathrm{km}^{3}$ & $\begin{array}{l}\% \text { of Lena } \\
\text { runoff }\end{array}$ \\
\hline A & Kusur station/Lena basin outlet & 70.68 & 127.39 & 2430 & 100.0 & 528.0 & 100.0 \\
\hline $\mathrm{B}$ & Verhoyanski Perevoz/Aldan sub-basin outlet & 63.32 & 132.02 & 696 & 28.6 & 163.9 & 31.0 \\
\hline $\mathrm{C}$ & Tabaga station/Upper Lena basin & 61.83 & 129.60 & 897 & 36.9 & 221.0 & 41.9 \\
\hline $\mathrm{D}$ & Hatyrik-Homo/Vilui valley outlet & 63.95 & 124.83 & 452 & 18.6 & 46.0 & 8.7 \\
\hline $\mathrm{E}$ & Suntar station/middle of Vilui valley & 62.15 & 117.65 & 202 & 8.3 & 23.5 & 4.4 \\
\hline $\mathrm{F}$ & Marha station/Marha tributary to the Vilui valley & 63.50 & 117.03 & 87 & 3.6 & 12.7 & 2.4 \\
\hline
\end{tabular}


between the pre- and post-dam periods so as to quantify reservoir impact on stream thermal regimes. Third, we carried out trend analysis and statistical significance test to define the long-term changes in stream temperatures by a linear regression. The total trend for the study period was defined by the difference of stream temperatures shown on the regression line between the first year and the last year. The standard $t$-test was used to determine the statistical significance of the trends. In order to show the statistical significances of trends, various confidence levels were used in trend descriptions. The results of trend and regime analyses were compared among the sub-basins to determine and understand the regional differences in stream thermal characteristics. Finally, we calculated the heat flux at the Lena basin outlet and determined its regime and change.

\section{Stream temperature regimes and changes}

In this section we define stream temperature seasonality and variation, and identify different characteristics of water temperature changes among the sub-basins/regions, i.e. the Aldan, upper Lena, Vilui valley, and the Lena basin outlet.

\subsection{Aldan tributary}

The Aldan tributary occupies the southeast corner of the Lena basin, close to the Pacific Ocean. The mountains and Aldan plateau that surround the Aldan valley are the water sources to the tributary. The area of this sub-basin is $696,000 \mathrm{~km}^{2}(28.6 \%$ of the Lena watershed), and it contributes $30 \%$ of the total Lena basin streamflow (Ye et al., 2003). Human activities in this region are insignificant, and no major dams exist in this tributary.

Long-term mean warm (open water) season stream temperatures near the Aldan's outlet, the Verhoyanski Perevoz station (station B in Fig. 1), show a period of increasing temperature (from 0.2 to $14.9{ }^{\circ} \mathrm{C}$ ) from May 20 to June 30, a relatively stable high temperature period (about $17.2-17.8{ }^{\circ} \mathrm{C}$ ) from July 10 to August 10, and a period of decreasing temperature (from 15.9 to $0.4{ }^{\circ} \mathrm{C}$ ) from August 20 to October 20, with the maximum stream temperature of $17.8{ }^{\circ} \mathrm{C}$ on July 20 (Fig. 2). During the first period, the rates of temperature increases are around $0.3-0.4{ }^{\circ} \mathrm{C} /$ day, with the greatest change of $0.5{ }^{\circ} \mathrm{C} /$ day occurring between May 30 and June 10. In the second period, stream temperatures vary very little. During the third period, the rates of temperature decreases are between 0.2 and $0.3{ }^{\circ} \mathrm{C}$ /day from August 20 to October 20, while relatively larger temperature changes $\left(-0.3{ }^{\circ} \mathrm{C} /\right.$ day $)$ occur from September 10 to October 10. The interannual variation of stream temperatures at this location is stable over the open water season. Although the long-term mean stream temperatures vary widely from $3{ }^{\circ} \mathrm{C}$ to $18{ }^{\circ} \mathrm{C}$ over the season, their standard deviations are found to be between $1.8^{\circ} \mathrm{C}$ and $2.0{ }^{\circ} \mathrm{C}$ during the open water season, except for May 20, October 10 and 20 with the standard deviations of $0.3{ }^{\circ} \mathrm{C}, 1.1^{\circ} \mathrm{C}$, and $0.5^{\circ} \mathrm{C}$, respectively.

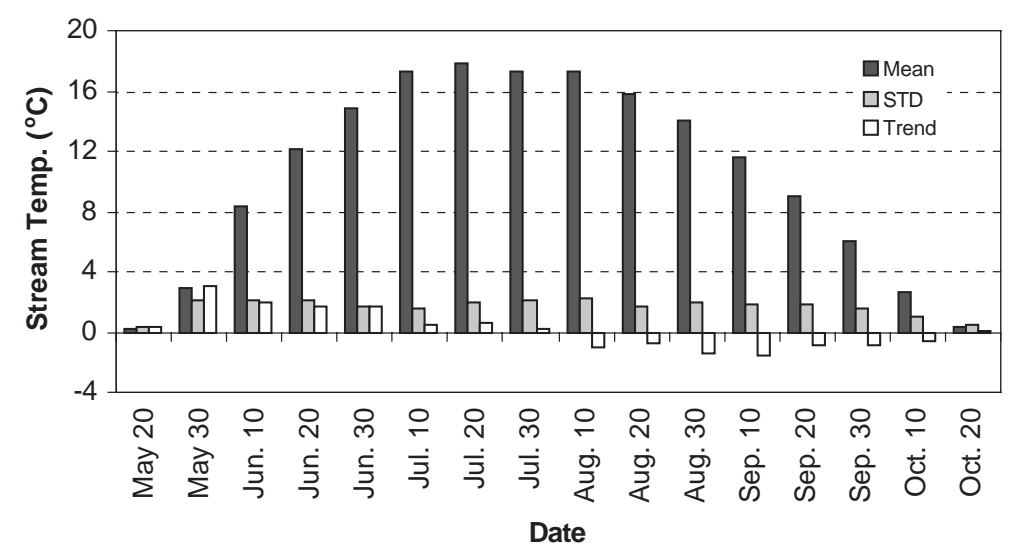

Fig. 2. Long-term mean open water season stream temperature, standard deviation, and trend for the Aldan tributary, $1950-1992$. 
Trend analyses for the stream temperature data over the period 1950-1992 reveal warming and cooling trends before and after July 30 (Fig. 2). Warming rates between $0.4{ }^{\circ} \mathrm{C}$ and $3.0{ }^{\circ} \mathrm{C}$ from May 20 to June 30 are statistically significant at an $85-98 \%$ confidence level. Stream temperature also weakly increased by $0.4{ }^{\circ} \mathrm{C}, 0.6{ }^{\circ} \mathrm{C}$, and $0.2{ }^{\circ} \mathrm{C}$ on July 10 , July 20 , and July 30 , respectively, although these changes are less statistically significant $(12-47 \%$ confidence level). From August 10 to October 10, cooling trends were found between $-1.6{ }^{\circ} \mathrm{C}$ and -0.6 ${ }^{\circ} \mathrm{C}$. These negative changes were generally statistically significant at a $64-90 \%$ confidence level, and the trends on August 30 and September $10\left(-1.4{ }^{\circ} \mathrm{C}\right.$ and $-1.6{ }^{\circ} \mathrm{C}$, respectively) are statistically significant at higher confidence levels of $84 \%$ and $90 \%$, respectively. Stream temperatures also very weakly decreased by $0.1{ }^{\circ} \mathrm{C}$ on October 20. Comparisons of the long-term mean stream temperatures between the 1950-1960s and 1970-1980s confirm that, relative to the earlier period, the mean temperatures during 1971-1992 are warmer (cooler) during the first-half (second-half) of the open water season (Fig. 3). These positive and negative changes in stream temperatures over the Aldan regions indicate a stream temperature regime shift toward early open water season.

\subsection{The Upper Lena}

The upper Lena region, $897,000 \mathrm{~km}^{2}(36.9 \%$ of the Lena watershed) above the Tabaga station (station $\mathrm{C}$ in Fig. 1), covers the mountain regions in the southwest corner of the Lena catchment. It contributes $42 \%$ of the basin total flow. Natural conditions remain in most areas, and no large reservoirs exist in this sub-basin.

In the upper Lena region, the long-term mean stream temperatures (represented by station Tabaga, C in Fig. 1) show a similar regime to that of the Aldan tributary, i.e. a period of rising temperature (0.3-15.2 ${ }^{\circ} \mathrm{C}$ ) from May 20 to June 30, a relatively stable high stream temperature period $\left(17.6-18.7^{\circ} \mathrm{C}\right)$ from July 10 to August 10, and an extended period of falling temperature $\left(17.1-0.1{ }^{\circ} \mathrm{C}\right)$ from August 20 to October 30 (Fig. 4). Unlike the Aldan tributary, the maximum stream temperature $\left(18.7^{\circ} \mathrm{C}\right)$ usually occurs on August 10 in the upper Lena region, this is probably due to the difference in regional climatic conditions. During the first period, the rates of temperature changes are about $0.3{ }^{\circ} \mathrm{C} /$ day from May 20 to May $30,0.6{ }^{\circ} \mathrm{C} /$ day during May 30-June $10,0.4{ }^{\circ} \mathrm{C}$ /day during June $10-20$, and 0.2 /day during June $20-30$. During the second period, stream temperatures vary very little. During the third period, the rates of temperature decrease vary in a relatively small range $\left(0.2-0.3{ }^{\circ} \mathrm{C} /\right.$ day $)$ from August 20 to October 20. Larger temperature changes $(-0.3$ ${ }^{\circ} \mathrm{C} /$ day) occur during August 30 to September 30 (Fig. 4). The inter-annual variation of stream temperature at this location is stable (standard deviation between $1.2{ }^{\circ} \mathrm{C}$ and $2.3^{\circ} \mathrm{C}$ ) over the warm season, except for May $20\left(0.4^{\circ} \mathrm{C}\right)$, October $20\left(0.5^{\circ} \mathrm{C}\right)$, and October $30\left(0.3^{\circ} \mathrm{C}\right)$.

Stream temperature changes over the upper Lena during 1950-1992 are characterized by positive trends

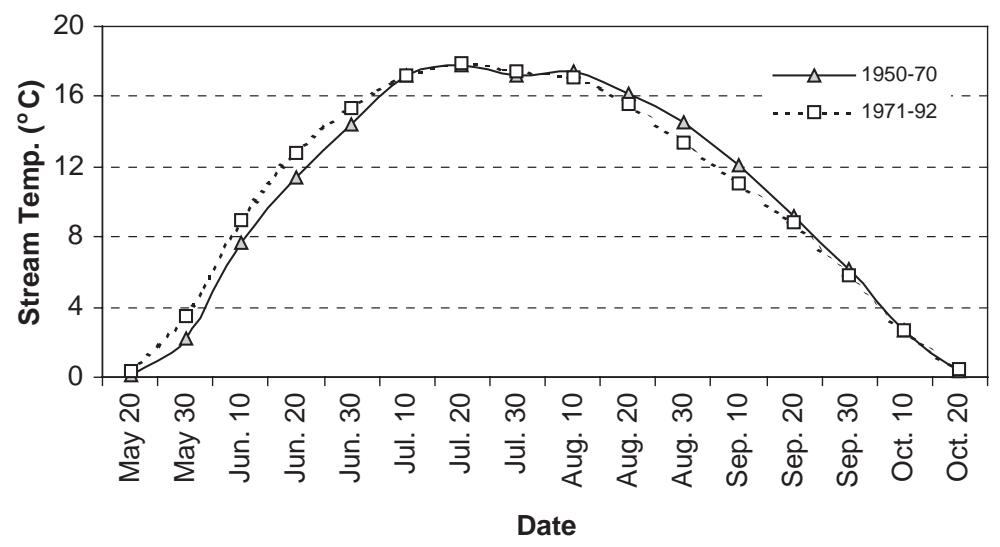

Fig. 3. Comparison of long-term mean stream temperature between 1950-1970 and 1971-1992 for the Aldan tributary. 


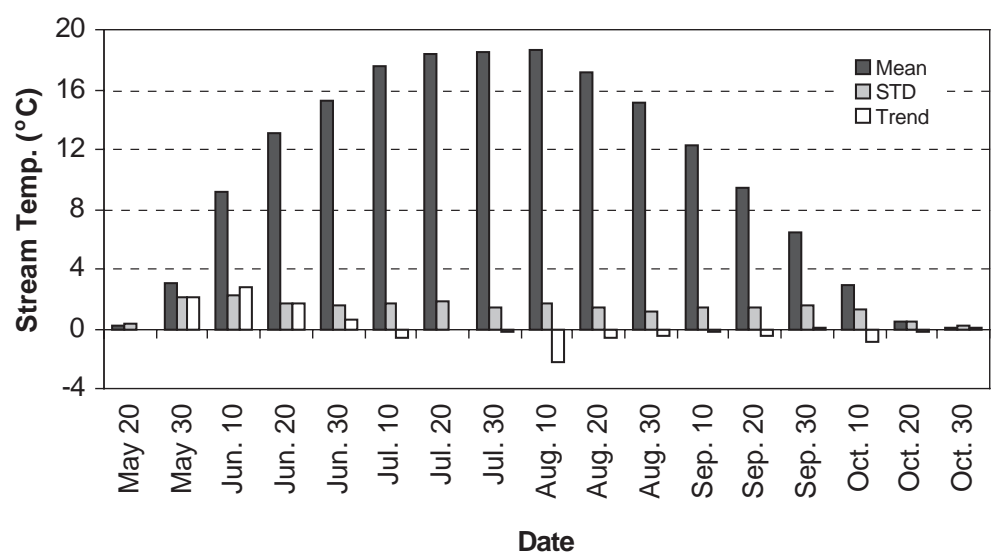

Fig. 4. Long-term mean open water season stream temperature, standard deviation, and trend for the upper Lena sub-basin, $1950-1992$.

from May 20 to June 30 and negative trends from July 10 to October 20 (Fig. 4). Relative to the Aldan region, the warming trends over the upper Lena are found only in the early open water season, and cooling trends are observed during mid-late open water season. Warming trends before June 30 (except May 20) are between $0.6{ }^{\circ} \mathrm{C}$ and $2.8{ }^{\circ} \mathrm{C}$ and they are statistically significant at a $93-98 \%$ confidence level, except for June 30 at the $50 \%$ confidence level. On the other hand, cooling trends are between $-2.2{ }^{\circ} \mathrm{C}$ and $-0.1{ }^{\circ} \mathrm{C}$ during July 10 to October 20 and generally less significant (below 60\% confidence level). Trends on August 10 and October 10 are $-2.2{ }^{\circ} \mathrm{C}$ and -0.8 ${ }^{\circ} \mathrm{C}$, respectively, and statistically significant at a higher level of confidence $(98 \%$ and $74 \%$, respectively). Comparisons of the long-term mean stream temperatures between the two periods, $1950-1970$ vs.
1971-1992, clearly show stream temperature increases during May 30 to June 20 and decreases from July10 to September 10 (Fig. 5). These results are consistent with the pattern of stream temperature trends in the upper Lena region.

\subsection{Vilui tributary}

The Vilui tributary, located in the west Lena basin, area $452,000 \mathrm{~km}^{2}(18.6 \%$ of Lena catchment), contributes $9 \%$ of the yearly total runoff in the Lena River. A large reservoir was built in the 1960s at the upper Vilui valley near Chernyshevskyi $\left(112^{\circ} 15^{\prime} \mathrm{W}\right.$, $\left.62^{\circ} 45^{\prime} \mathrm{N}\right)$. The rock-filled dam, $75 \mathrm{~m}$ high and $600 \mathrm{~m}$ long, was completed in 1967. The maximum reservoir capacity is $35.9 \mathrm{~km}^{3}$, about $7 \%$ of the total annual runoff $\left(524 \mathrm{~km}^{3}\right)$ of the Lena River, or 1.8 times of the

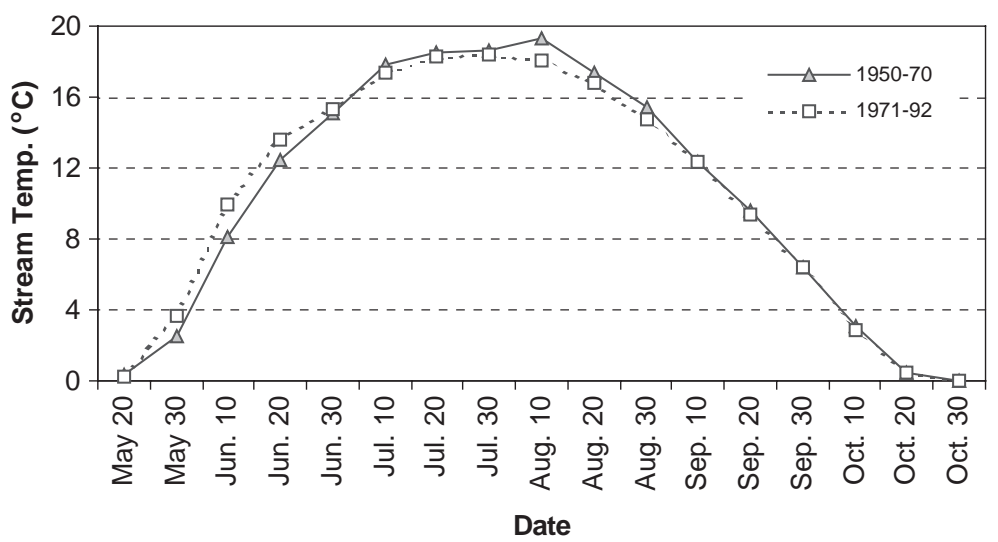

Fig. 5. Comparison of long-term mean stream temperatures between 1950-1970 and 1971-1992 at the upper Lena outlet. 
total discharge $\left(20 \mathrm{~km}^{3}\right)$ at the Chernyshevskyi station in the Vilui valley. The reservoir reached its designed stage during the spring of 1972 , with the total reservoir area exceeding $2100 \mathrm{~km}^{2}$ (Kane, 1974). The reservoir is used primarily for electric power generation. The reservoir holds water in spring and summer seasons to reduce snowmelt and rainfall floods and releases water from near the bottom of the reservoir to meet the demand for power generation in winter (Ye et al., 2003).

Studies show that reservoir regulation alters streamflow seasonal cycle (Shiklomanov et al., 2000; Ye et al., 2003) and affect thermal regime in the downstream river (Gosink, 1986; Webb and Nobilis, 1995). To quantify the effect of reservoir on downstream stream temperature characteristics, we examined the stream temperature records at two gauging stations along the Vilui valley. Unfortunately we do not have water temperature data near the dam site where the effect of the regulation on streamflow is most significant (Ye et al., 2003). Stream temperature data collected at the Suntar station (station E in Fig. 1), located about $350 \mathrm{~km}$ downstream of the dam, demonstrate reduced but significant impact of reservoir regulation. For instance, since 1966, the summer peak flows in June have been reduced from 2500$8200 \mathrm{~m}^{3} / \mathrm{s}$ to $700-3000 \mathrm{~m}^{3} / \mathrm{s}$ and consequently water temperatures on June 20 have suddenly risen from 8$14{ }^{\circ} \mathrm{C}$ to $10-16{ }^{\circ} \mathrm{C}$ (Fig. 6a). To better understand the impact of reservoir regulation on stream temperatures, we examined the relationship between discharge and stream temperature at the Suntar station for the preand post-dam periods. The results show that the stream temperature at the Suntar station was strongly

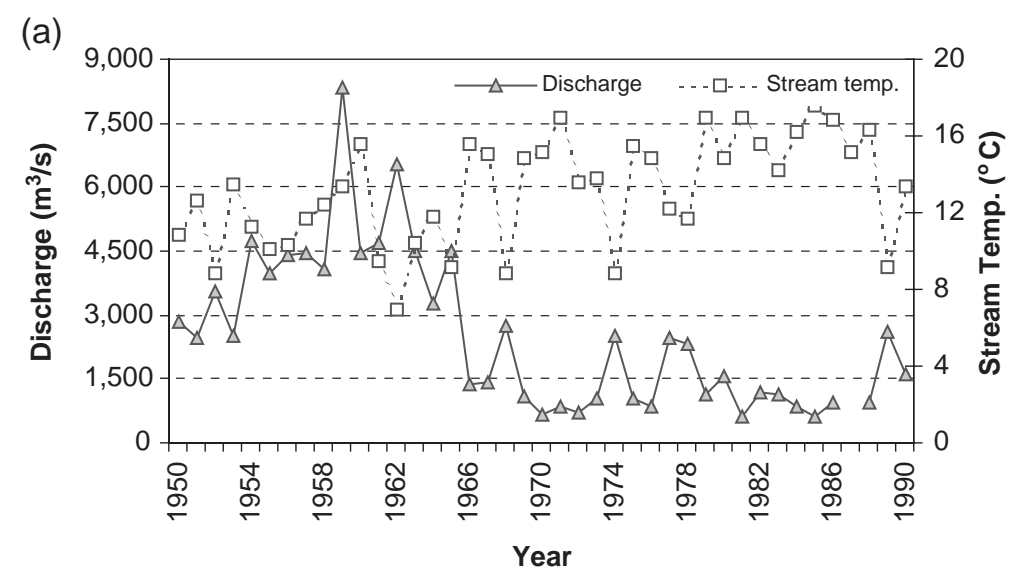

(b)

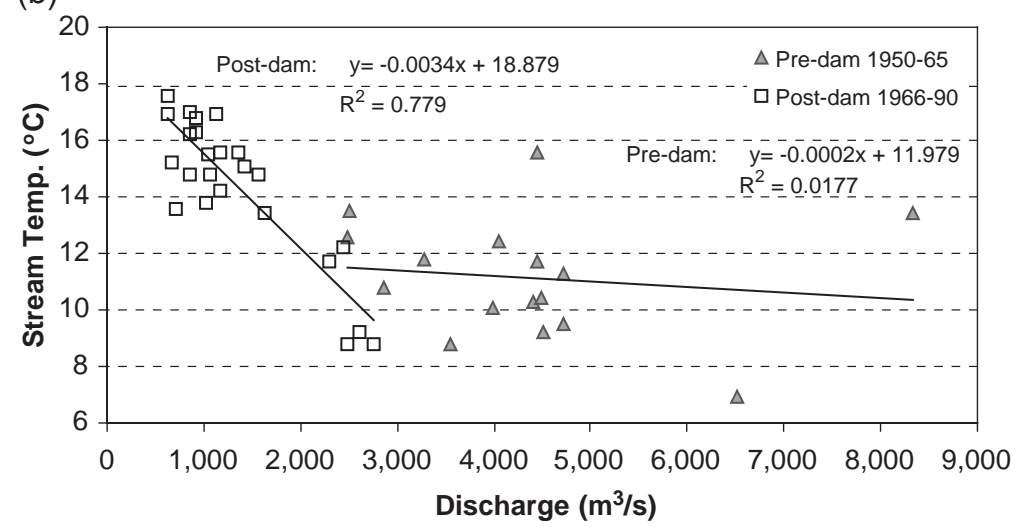

Fig. 6. Correlation between June discharge and June 20th stream temperature at the Suntar station, (a) discharge and water temperature time series during 1950-1992, (b) scatter plot and linear regression for the pre- and post-dam periods. 
negatively correlated with discharge during the postdam period, i.e. higher stream temperatures were associated with lower discharge (Fig. 6b). Furthermore, comparisons of long-term mean open water season stream temperatures between the pre- and post-dam periods show remarkable changes. The post-dam temperatures were $2-5{ }^{\circ} \mathrm{C}$ higher from May 30 to June $20,2-3{ }^{\circ} \mathrm{C}$ lower from July 10 to August 10, and close from August 20 to October 20 (Fig. 7a). This seems reasonable, because less water could be relatively easier to be warmed up. In addition, relative to the natural flow, water released from near the reservoir bottom is usually warmer in the early open water season and cooler in the midsummer. These temperature changes demonstrate the impact of reservoir regulation on the downstream water thermal conditions.
It is important to note that water temperatures in the unregulated tributaries within the Vilui valley show weak changes over the past decades. For example, comparisons of long-term mean temperatures between pre-dam 1950-1965 and post-dam 1966-1992 periods at the Marha station located in the unregulated tributaries (station F in Fig. 1) show weak increases (generally less than $1{ }^{\circ} \mathrm{C}$ ) in the early and late parts of the warm season, and little changes in the mid-summer (Fig. 7b). These differences are much smaller than those found in the regulated regions and they indicate less change in stream temperature under natural conditions. On the other hand, stream temperature changes in the regulated regions have altered water temperature regime toward early warming and lower maximum in the mid-summer. The impacts of this regime shift on

(a)

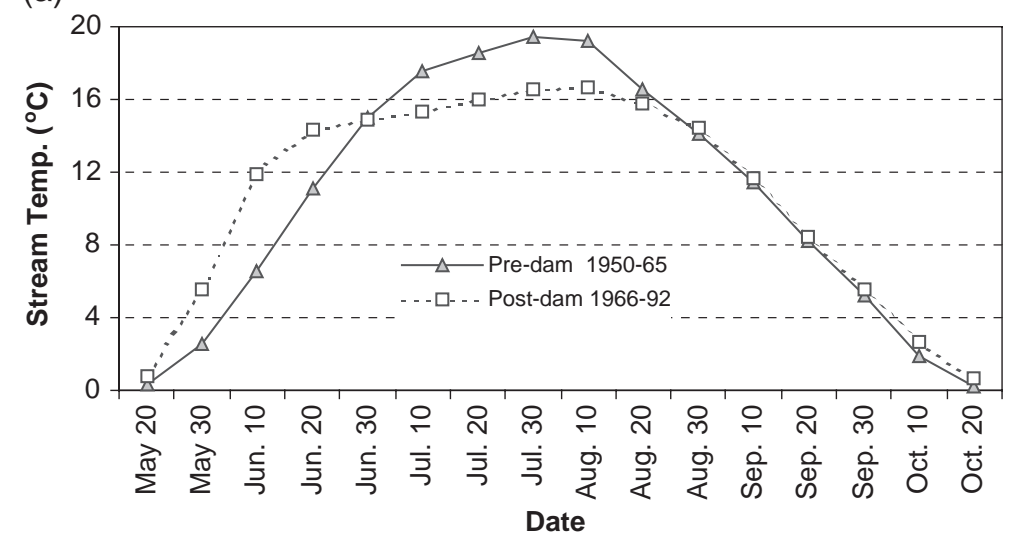

(b)

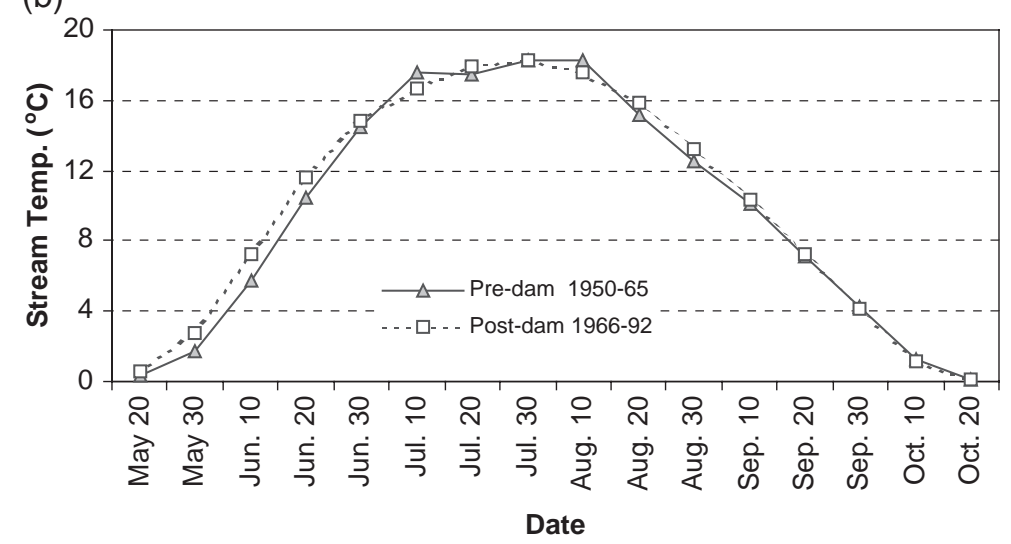

Fig. 7. Comparison of long-term mean stream temperature between pre-dam (1950-1965) and post-dam (1966-1992) periods at the regulated Suntar station (a), and unregulated Marha station (b). 


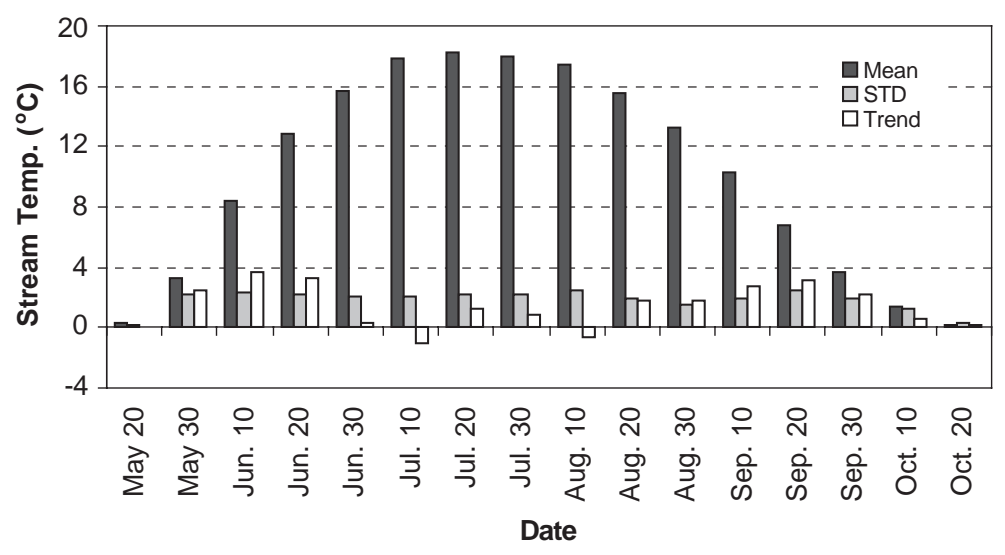

Fig. 8. Long-term mean open water season stream temperature, standard deviation, and trend at the Vilui valley outlet, $1950-1992$.

local ecological and biological systems need to be assessed.

Further downstream from the dam, the reservoir's influence became relatively weaker due to the runoff contribution from other unregulated tributaries. Winter flow rise (about $500 \mathrm{~m}^{3} / \mathrm{s}$ ) is still visible at the Hatyrik-Homo station near the Vilui valley outlet, and summer peak discharge was substantially reduced from $4000-15,000 \mathrm{~m}^{3} / \mathrm{s}$ to $3000-10,000 \mathrm{~m}^{3} / \mathrm{s}$ (Ye et al., 2003). The long-term mean stream temperatures over the Vilui sub-basin (represented by Hatyrik-Home station, D in Fig. 1) shows a very similar seasonal cycle to those of the other two sub-basins (Fig. 8). The inter-annual variations of stream temperatures over the Vilui sub-basin are stable with standard deviations between
$0.3{ }^{\circ} \mathrm{C}$ and $2.3{ }^{\circ} \mathrm{C}$ over the open water season. However, the differences in mean stream temperatures between pre- and post-dam periods are weak at the Vilui valley outlet. Relative to the pre-dam period, the mean temperatures at Vilui outlet $(900$ $\mathrm{km}$ downstream the dam) over the post-dam period are $1-2{ }^{\circ} \mathrm{C}$ higher during May 30-June 20 and September 10-20 (Fig. 9).

Over the period 1950-1992, stream temperatures at the Vilui outlet show warming trends over the open water season, except for July 10 and August 10 with weak cooling trends (Fig. 8). The upward trends are particularly strong (up to $2.5-3.6{ }^{\circ} \mathrm{C}$ ) during early open water season (May 30-June 20) mainly due to strong reservoir regulation-reduced peak flow in this period. Trends are weak and mixed in summer (June

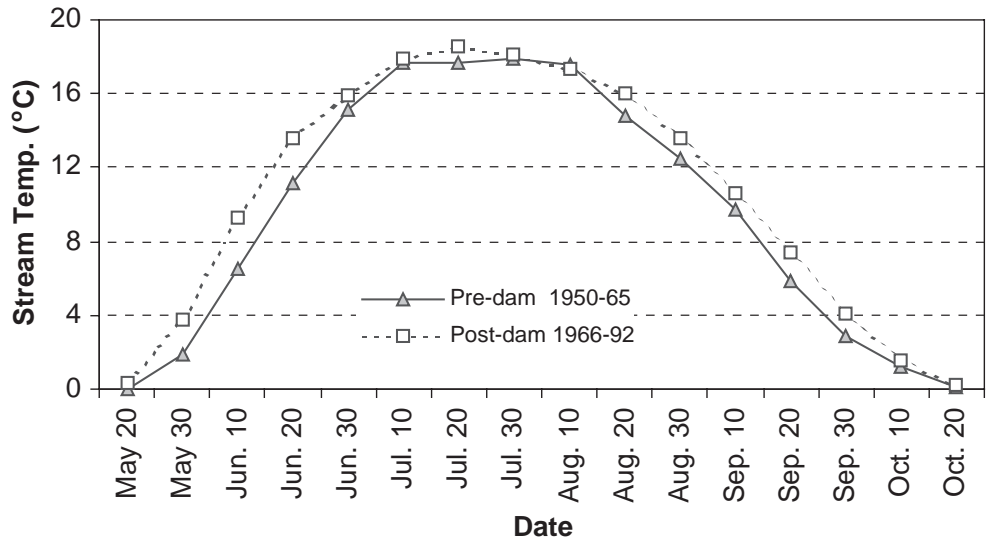

Fig. 9. Comparison of long-term mean stream temperatures between pre-dam (1950-1965) and post-dam (1966-1992) periods at the Vilui valley outlet. 


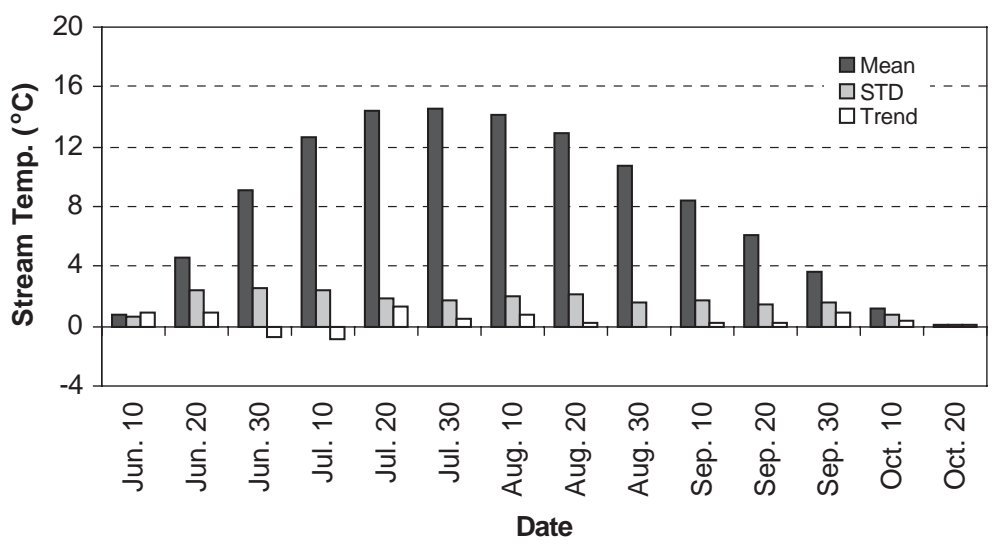

Fig. 10. Long-term mean warm season stream temperature, standard deviation, and trend at the Lena basin outlet, 1950-1992.

30-August 30) owing to higher streamflow contribution from unregulated tributaries and relatively weak reservoir impacts. The positive trends are strong (about 2.1-3.2 ${ }^{\circ} \mathrm{C}$ ) during late season (September 10-30), which indicate strong local warming since the reservoir regulation has no significant influence on the water temperature of the lower reach in the late openwater season.

\subsection{Lena Basin outlet}

Stream temperature data at the river mouth are particularly important as they represent the thermal conditions of the river influx to the ocean systems. It is thus critical to describe the fundamental characteristics of stream temperature at the basin outlet, and document any significant variations and changes.
The long-term mean open water season stream temperatures near the Lena basin outlet, the Kusur station (station A in Fig. 1), show similar characteristics to the sub-basins (Fig. 10). However, relative to the sub-basins, stream temperatures at the Lena basin outlet are 3-8 ${ }^{\circ} \mathrm{C}, 3-5{ }^{\circ} \mathrm{C}$, and $0-4{ }^{\circ} \mathrm{C}$ lower, respectively, in the early, mid-, and late open water season due to relatively cold climate in the northern Lena regions (Fig. 11). These temperature differences demonstrate climate control on regional stream temperature behaviors. Inter-annual variations in stream temperatures at the Lena basin outlet are found to be stable between $1.6{ }^{\circ} \mathrm{C}$ and $2.5^{\circ} \mathrm{C}$ for most of the warm season (Fig. 10). June is the period of peak flows, the relatively larger standard deviations in June (Fig. 10) indicate greater fluctuations in river thermal flux during the snowmelt period.

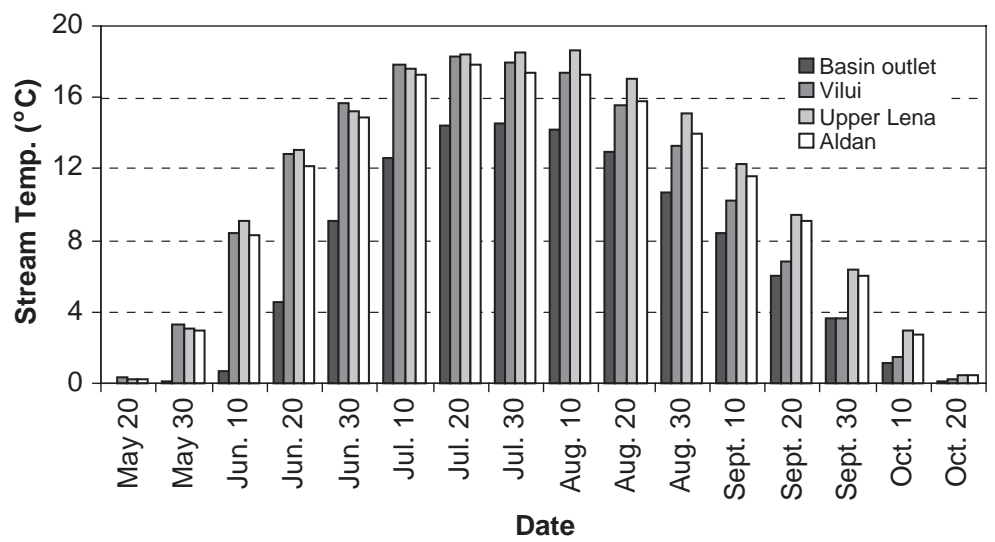

Fig. 11. Comparison of long-term (1950-1992) mean stream temperatures among the sub-basins and Lena basin outlet. 
Stream temperature records at the Kusur station during 1950-1992 show weaker changes relative to those in the southern sub-basins (Fig. 12). This is reasonable as the magnitudes of changes usually decease with increase in basin size. Trend on May 20 and 30 cannot be determined at the Kusur station due to many missing dada. Positive trends are $1.0{ }^{\circ} \mathrm{C}$ (statistically significant at the $99 \%$ confidence level) on June 10 , and $0.9{ }^{\circ} \mathrm{C}$ (statistically significant at the $52 \%$ confidence level) on June 20 , respectively, at the basin outlet. These changes are consistent with the strong positive trends in the upper basin, particularly in the Vilui due to the reservoir regulation. This consistency in trends over various parts of the watershed indicates a general warming tendency throughout the entire basin during this period, although the trends are weaker in magnitude at the basin scale perhaps due to runoff contribution and difference of energy balance in the northern Lena regions. This consistent warming trend may have enhanced the thermal erosion along the riverbanks, because warmer water temperatures result in greater erosion rates in the Lena basin (Costart et al., 2003).

During June 30 and July 10, cooling trends of about $1{ }^{\circ} \mathrm{C}$ were found at the Kusur station, while the upper basins show warming trends on June 30 and mixed changes on July 10 (Fig. 12). Correlation analyses show no coherences of water temperatures on June 30 and July 10 between the Kusur station and the sub-basins. Similar cooling trends in water temperatures were also found in other coastal river basins near the Lena watershed. Thus the negative changes detected at the Lena basin outlet may indicate a regional response to a cooling tendency of air temperatures over the northern coastal regions in these periods. During July 20 to August 10, significant positive trends of $0.8-1.3{ }^{\circ} \mathrm{C}$ were observed at the Kusur station. The Vilui and Aldan sub-basins also show positive trends during July 20-30 and the upper Lena has little change (Fig. 12). Trends on August 10 were not consistent, as the sub-basins have negative changes, particularly in the upper Lena regions with a very strong cooling trend (Fig. 12). This discrepancy in trends probably suggests that other factors, such as rainfall runoff contribution over the northern Lena basin, may also affect water temperature change at regional scales. During August 20 to October 20, stream temperatures trends at the Kusur station are very weak (less than $0.5{ }^{\circ} \mathrm{C}$ over the study period) (Fig. 12). Strong upward trends were found in the regulated Vilui valley and moderate downward trends were seen over the upper Lena basin. These different trends among the sub-basins cancel each other through basin integration (mixing of flows from sub-basins) over the northern parts of watersheds, leading to weaker trends at the basin outlet.

To understand the climatic influence on river thermal conditions, we examined the relationship of air temperature and precipitation vs. water temperature over the Lena basin as whole. We correlate monthly basin mean air temperature and precipitation with stream temperatures collected on the 20th day of

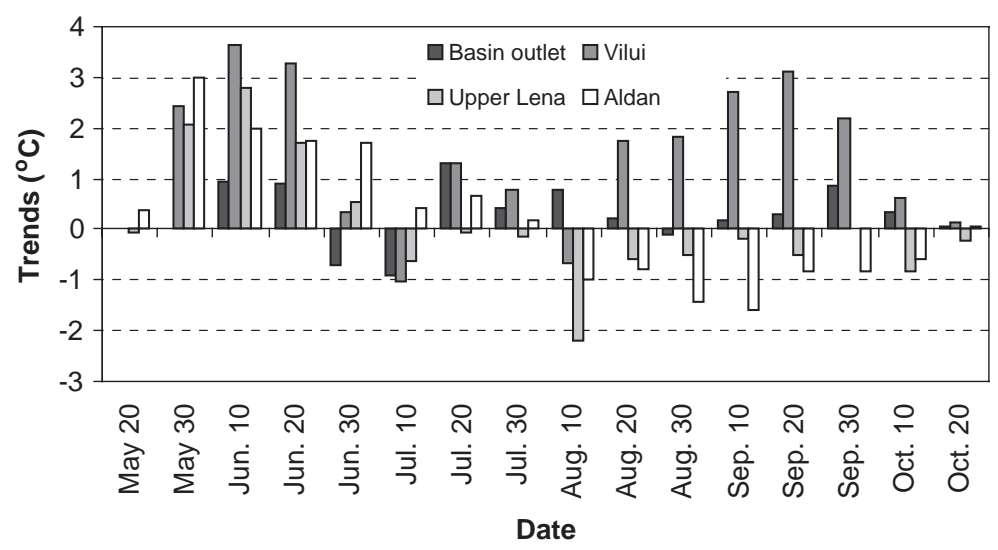

Fig. 12. Trends of long-term open water season stream temperature measurements for the major sub-basins and at the Lena basin outlet. 


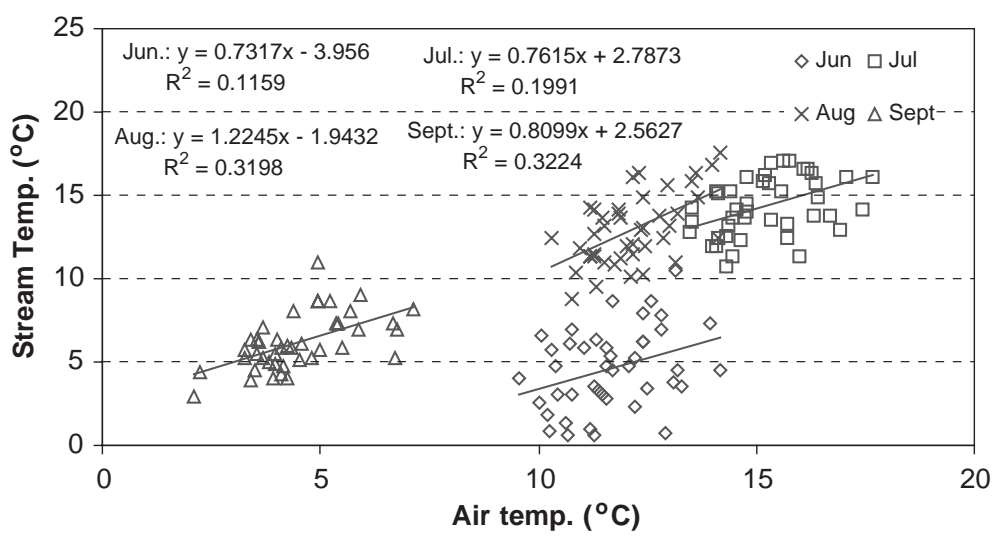

Fig. 13. Scatter plots and results of regression between the Lena-basin-mean monthly air temperature and stream temperature measured at the basin outlet.

the month at the basin outlet. The results show statistically significant (95-99\% confidence level) positive correlations between stream and air temperatures during the open water season (Fig. 13). The correlations are higher in August and September (statistically significant at the $99 \%$ confidence level), indicating a stronger association of stream temperatures with air temperature in the late open water season. On the other hand, the correlations between stream temperature and precipitation are very weak and statistically insignificant. These results show that air temperature has strong association with stream thermal characteristics in the Lena basin. In addition to air temperature and precipitation, solar radiations also affect river thermal regimes (Sinokrat and Stefan, 1993). The impact of radiations on the Lena River water temperatures needs to be assessed when radiation data become available.

\section{Calculation of Lena River total heat content}

Monthly heat flux from the Lena basin was calculated for June through September using the following equation (Elshin, 1981):

$H=0.3615 Q T n$

where $H$ is the total heat flux in a given month $\left(10^{6}\right.$ MJ), $Q$ and $T$ are the monthly mean discharge $\left(\mathrm{m}^{3} / \mathrm{s}\right)$, and the monthly mean stream temperature $\left({ }^{\circ} \mathrm{C}\right)$ at the basin outlet, and $n$ is the number of days in a given month. The coefficient, 0.3615 , has the dimensions of $10^{6} \mathrm{MJs} /\left({ }^{\circ} \mathrm{C}\right.$ day $\left.\mathrm{m}^{3}\right)$ according to unit conversion, and the value of specific heat of water is $4.184 \mathrm{~J} /\left({ }^{\circ} \mathrm{C} \mathrm{g}\right)$ in calculation. Monthly mean stream temperature $(T)$ is estimated by averaging two observations taken on the 10th and 20th days of a month. When a $T$ record is missing for a specific year, the long-term mean value is used as an estimate. Comparisons of various methods to determine monthly mean water temperatures show that the method we used here is representative and conservative, as it does not overestimate the mean temperatures during most open water season.

Results of the heat flux calculations are summarized in Fig. 14. It shows that mean monthly values are between $1922 \times 10^{9} \mathrm{MJ}$ in September to $607 \times 10^{9} \mathrm{MJ}$ in July, with the total being $14,281 \times 10^{9}$ MJ during June through September. It is important to notice the difference and similarity in seasonal cycles among river discharge, water temperature and heat flux. The Lena river discharge peaks in June, and the highest water temperature coincides with the maximum heat flux in July. The standard deviations of the monthly heat fluxes vary in a small range from 777 in September to $1258 \times 10^{9} \mathrm{MJ}$ in July, while heat flux trends show moderate increases of $311-477 \times 10^{9} \mathrm{MJ}$ during June to August and a weak decline of $202 \times 10^{9}$ MJ in September, which are statistically significant at a $45-60 \%$ confidence level. The heat flux increase in June is the highest $(23 \%$ of the long term mean) owing to the combined effect of peak flow increase (Ye et al., 2003) and stream temperature 


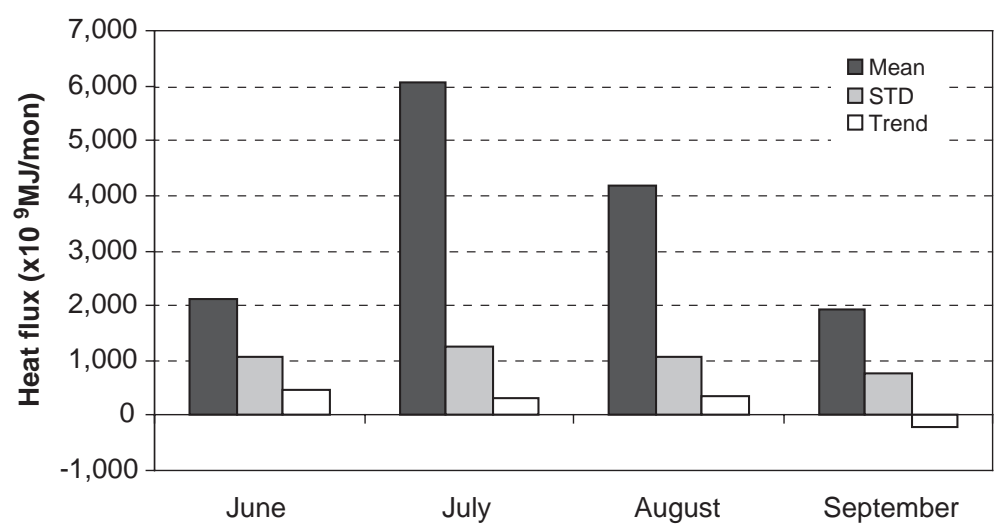

Fig. 14. Long-term mean Lena river heat flux, standard deviation, and trend at the Lena basin outlet, 1950-1992.

warming over the Lena basin. The impact of changes in large northern river thermal flux to the Arctic Ocean needs research attention.

\section{Conclusion}

The goals of this paper are to describe the stream temperature regimes over the various parts of the Lena watershed and document significant stream temperature changes induced by reservoir regulation and natural variations/changes. On the basis of systematic analyses of long-term stream temperature records at the major gauging stations within the Lena watershed, we found that the open water season can be divided into three consecutive stages- - increasing temperature stage" in the early open water season, "stable temperature stage" in the mid-warm season, and "decreasing temperature stage" in the late open water season. Temperature conditions are similar over the Aldan and upper Lena regions. However, stream temperatures at the Lena basin outlet are up to $8{ }^{\circ} \mathrm{C}$ colder than those over the southern sub-basins. This suggests that the latitudinal difference in climatic variables, such as air temperature, may be the major control on stream temperature regime.

This study also found that the reservoir regulation has a strong influence on the regional water temperature regime and change in the regulated sub-basin. For the downstream Vilui valley, the reservoir acts as a warm source in May and June, and a cold source in July and August. Relative to the pre-dam condition, post-dam mean water temperatures at the Suntar station have increased by $2-5{ }^{\circ} \mathrm{C}$ in the early open water season, and decreased by about $2-3{ }^{\circ} \mathrm{C}$ in the mid-open water season. As a result, the seasonal cycle of water temperature has shifted toward an earlier warm season. Generally, the water released from the reservoir has increased (reduced) the downstream water temperatures in the Vilui valley during the early (mid) open water season, and the reservoir has not significantly influenced downstream water temperatures in the late open water season.

Trend analyses of stream temperature records during 1950-1992 show consistent warming trends across the entire Lena River basin in the early open water season. This may indicate a response to earlier snowmelt over the Lena River watershed. Trend results also demonstrate regional characteristics in long-term water temperature changes over the open water season. The Aldan tributary has warming (cooling) trends in the first (second) half of the open water season, leading to a stream temperature regime shift toward early open water season. The upper Lena River shows warming trends in the early open water season, and cooling trends over the mid-late season. Over the regulated Vilui tributary, however, stream temperatures have significantly increased in the early and late parts of the season under the combined effects of natural changes and reservoir regulation. Over the Lena basin as a whole, positive changes in stream temperature have been discovered during the early and mid-June. River discharge also increased in this peak flow period (Ye et al., 2003). As a result, the heat flux has increased in June by $23 \%$ over the Lena basin. The impact of this change to thermal erosions 
along the river valley and to the Laptev Sea needs research attention.

\section{Acknowledgements}

This study was supported by the NSF grant 0230083, NOAA/CIFAR grant NA 17RJ1224, and Natural Sciences Foundation of China (NSFC) grant 499714022. The authors appreciate two anonymous reviewers for their constructive comments and suggestions.

\section{References}

Aagaard, K., Carmack, E.C., 1989. The role of sea ice and other fresh water in the arctic circulation. Journal of Geophysical Research 94 (C10), 14485-14498.

Bareiss, J., Eicken, H., Helbig, A., Martin, T., 1999. Impact of river discharge and regional climatology on the decay of sea ice in the Laptev Sea during spring and early summer. Arctic, Antarctic, and Alpine Research 31 (3), 214-229.

Brown, G.W., 1969. Predicting temperatures of small streams. Water Resources Research 5, 68-75.

Costart, F., Dupeyrat, L., Gautier, E., Carry-Gailhardis, E., 2003. Fluvial thermal erosion investigation along a rapid eroding river bank: application to the Lena river (central Siberia). Earth Surface Processes and Landforms 29, 1349-1359.

Dynesius, M., Nilsson, C., 1994. Fragmentation and flow regulation of river systems in the northern third of the world. Science 266, $753-762$.

Elshin, Yu., 1981. River heat runoff in the European part of Russia. Meteorology and Hydrology 9, 85-93.

Gosink, J.P., 1986. Synopsis of analytic solutions for the temperature distribution in a river downstream from a dam or reservoir. Water Resources Research 22 (6), 979-983.

Grabs, W.E., Fortmann, F., De Couuel, T., 2000. Discharge observation networks in Arctic regions: computation of the river runoff into the Arctic Ocean, its seasonality and variability. In: Lewis, E.L., Jones, E.P., Lemke, P., Prowse, T.E., Wadhams, P. (Eds.), The Freshwater Budget of the Arctic Ocean Proceedings of the NATO Advanced Research Workshop, Tallin, Estonia, 27 April-1 May 1998. Kluwer Acad, Norwell, Mass., pp. 249-268.

Hynes, H.B.N., 1970. The Ecology of Running Waters. University of Toronto Press, Toronto. $555 \mathrm{pp}$.

Kane, D.L., 1974. A review of dam construction techniques in permafrost regions. Northern Engineer 6 (1), 25-29.

Lake, J.S., 1967. Principal fishes of the Murray-Darling River system. In: Weatherly, A.H. (Ed.), Australian Inland Waters and their Fauna: Eleven Studies, Australian National University Press, Canberra, pp. 192-213.
Lammers, R., Shiklomanov, A., Vorosmarty, C., Fekete, B., Peterson, B., 2001. Assessment of contemporary arctic river runoff based on observational discharge records. Journal of Geophysical Research 106 (D4), 3321-3334.

Lowney, C.L., 2000. Stream temperature variation in regulated rivers: evidence for a spatial pattern in daily minimum and maximum magnitudes. Water Resources Research 36 (10), 2947-2955.

Mackay, J.R., Mackay, D.K., 1975. Heat energy of the Mackenzie River. Further hydrologic studies in the Mackenzie Valley, Canada. Environmental-Social Committee Northern Pipelines. Task Force on Northern Oil Development report, Report 74-35. Information Canada, Ottawa, pp. 1-23.

Marsh, P., Prowse, T.D., 1987. Water temperature and heat flux at the base of river ice covers. Cold Regions Science and Technology 14, 33-50.

New, M.G., Hulme, M., Jones, P.D., 2000. Representing twentiethcentury space-time climate variability: Part II. Development of 1901-1996 monthly grids of terrestrial surface climate. Journal of Climate 13, 2217-2238.

Nijssen, B., O’Donnell, G., Lettenmaier, D.P., Lohmann, D., Wood, E., 2001a. Predicting the discharge of global rivers. Journal of Climate 15, 3307-3323.

Nijssen, B., O’Donnell, G., Hamlet, A.F., Letternmaier, D.P., 2001 b. Hydrologic sensitivity of global rivers to climate change. Climatic Change 50, 143-175.

Peterson, B.J, Holmes, R.M., McClelland, J.W., Vörösmarty, C.J., Lammers, R.B., Shiklomanov, A.I., Shiklomanov, I.A., 2002. Increasing river discharge to the Arctic Ocean. Science 298 (5601), 2171-2173.

Petts, G.E., 1986. Water quality characteristics of regulated rivers. Progress in Physical Geography 10, 492-516.

Preece, R.M., Jones, H.A., 2002. The effect of Keepit Dam on the temperature regime of the Namoi River, Australia. River Research and Applications 18, 397-414.

Prowse, T.D., Flegg, P.O., 2000. Arctic river flow: a review of contributing areas. In: Lewis, E.L., Jones, E.P., Lemke, P., Prowse, T.E., Wadhams, P. (Eds.), The Freshwater Budget of the Arctic Ocean, Proceedings of the NATO Advanced Research Workshop, Tallin, Estonia, 27 April-1 May 1998Kluwer Acad, Norwell, Mass, pp. 269-280.

Revenga, C., Murray, S., Abramovitz, J., Hammond, A., 1998. Watersheds of the World: Ecological Value and VulnerabilityWorld Resour. Inst. and World Watch Inst, Washington, DC, p. 164.

Serreze, M.C., Bromwich, D.H., Clark, M.P., Etringer, A.J., Zhang, T., Lammers, R.B., 2002. The large scale-hydro-climatology of the terrestrial arctic drainage system. Journal of Geophysical Research 107.

Shiklomanov, I.A., Shiklomanov, A.I., Lammers, R.B., Peterson, B.J., Vörösmarty, C.J., 2000. The dynamics of river water inflow to the Arctic Ocean. In: Lewis, E.L., Jones, E.P., Lemke, P., Prowse, T.E., Wadhams, P. (Eds.), The Freshwater Budget of the Arctic Ocean, Proceedings of the NATO Advanced Research Workshop, Tallin, Estonia, 27 April-1 May 1998. Kluwer Acad, Norwell, Mass, pp. 281-296. 
Sinokrat, B.A., Stefan, H.G., 1993. Stream temperature dynamics: measurement and modeling. Water Resources Research 29, 2299-2312.

Sridhar, V., Sansone, A.L., Lamarche, J., Dubin, T., 2004. Prediction of stream temperature in forested watersheds. Journal of the American Water Resources Association 40 (1), 197-213.

State Hydrologic Institute (SHI), 1961. Recommendation on Methods of Compiling Data on Water Resources, Issue 9, Thermal and Ice Conditions on Rivers. Leningrad, pp. 207 (in Russian).

State Hydrologic Institute (SHI), 1975. Handbook for hydrometeorological stations, Issue 2, Part II, Hydrological Observations. Leningrad, pp. 264 (in Russian).

Ward, J.A., Stanford, J.A., 1979. The Ecology of Regulated Streams. Plenum Press, New York. 398 pp.

Webb, B.E., Nobilis, F., 1995. Long term water temperature trends in Austrian rivers. Hydrological Sciences Journal 40 (1), 83-96.

Yang, D., Kane, D., Hinzman, L., Zhang, X., Zhang, T., Ye, H., 2002. Siberian Lena River hydrologic regime and recent change. Journal of Geophysical Research 107 (D23), 4694.
Yang, D., Robinson, D., Zhao, Y., Estilow, T., Ye, B., 2003. Streamflow response to seasonal snowcover extent changes in large Siberian watersheds. Journal of Geophysical Research 08 (D18), 4578.

Yang, D., Ye, B., Kane, D., 2004. Streamflow hydrology changes over Siberian Yenisei river basin. Journal of Hydrology 296 (1-4), 59-80.

Ye, B., Yang, D., Kane, D., 2003. Changes in Lena River streamflow hydrology: human impacts vs. natural variations. Water Resources Research 39 (7), 1200.

Zhang, T., Barry, R.G., Knowles, K., Heginbottom, J.A., Brown, J., 1999. Statistics and characteristics of permafrost and ground-ice distribution in the Northern Hemisphere. Polar Geography 23 (2), $132-154$.

Zhang, X., Harvey, K.D., Hogg, W.D., Yuzyk, T.R., 2001. Trends in Canadian streamflow. Water Resources Research 37, 987-998. 